The importance of the issue results from socio-economic challenges, European integration changes, the increasing role of the individual in social processes, the significance of individual social and professional skills and abilities associated with the permanent reforms in education, including primary education, lack of social competence-based programs for future primary school teachers in higher educational institutions, dominance of active teachers who entered the stage of professional development which can be called "conservation" and thus, require continuous training and skills improvement. The goal of the article is to highlight the results concerning one of the six components of primary school teachers' social competence, namely, personal and professional component in the process of postgraduate education, showing extensive potential of the system described to create appropriate facilities. It has been found out that the development of various components is unbalanced. It has been proved that there is positive dynamics of output and outcomes concerning the levels of the development of personal and professional component of social competence of the participants in the experimental group compared to those in the control group. The comparison of generalized arithmetic average results of the groups demonstrates substantial differences and points to the significant changes that occurred during the formative stage of pedagogical experiment, and thus proves the postgraduate education potential to create appropriate conditions for sustainable development.

Keywords: social competence, personal and professional component, primary school teacher, the system of postgraduate pedagogical education, results of the development.

\section{Introduction}

The personality of a teacher, his/her outlook, culture, spiritual and moral character, professionalism are the most disputable issues in any period of social development due to the crucial role of the individual in social progress in general and teachers in particular. These issues have been in the focus of both foreign and Ukrainian scientists' attention. Among the recent researches under consideration the following authors should be mentioned: S. Honcharenko [1], M. Doctorovych [2], V. Kudin [4], O. Savchenko [11], V. Sukhomlynsky [13, p. 455] and others. Despite numerous research attempts the problem remains relevant because, as V. Sukhomlynsky pointed out, a teacher is a person who on behalf of the people have daily access to the most valuable national wealth soul, mind, thoughts and feelings of a child and contributes to the most significant public creation - a human being $[13$, p. 455]. A teacher provides student's involvement into society, his or her social roles performance, harmonization of his or her own «Ego» with the interests of others, formation of social relations that meet a variety of needs (spiritual and physical), etc. Thus, this is in reference to social competence. Accordingly, a teacher must have a system of complex social skills to provide interaction of individual, group and state entities, typical behavior scenarios in social situations, a wide range of social roles to achieve positive personal and social outcome, that is to be socially competent.

It should be noted that the abovementioned is the priority of a new Ukrainian school conception. Among the ten competencies that modern pupils must acquire, we have singled out social competency as the ability to cooperate successfully, to prevent and resolve conflicts and reach compromises. The framework of the new Ukrainian school involves nine components relating to the new competency-based education content and schools structure aimed at successful fulfillment of a competent individual in social and private life; creation of a modern educational environment to ensure the necessary conditions, tools, learning technology for students, teachers and parents in school and out-of-school activity; childcentrism, that is focus on the needs of the student in the educational process; partnership pedagogy; a motivated teacher given the right for freedom of creative activity, who can develop professionally, etc. [7].

These days, a teacher, who is a specialist "with the appropriate professional psychological and pedagogical education, providing training and fulfilling educational work at secondary schools" [1, p. 86] cannot be considered a top-ranked specialist. A teacher should try to avoid the role of teacher-dictator or teacher-mentor who works by repeating the expressed ideas, learning by heart of what they say, expecting the answers they taught to give, etc. A teacher has to master the role of so called "teacher-guide- 
conductor" (being a "sculptor" to a certain extent, who seeks and develops unique students' qualities, stimulates them to get knowledge and be aware of scientific knowledge foundations, inspires them with the desire to cognize new ideas) and, on the other hand, the role of so called "teacher-plant selection breeder" (who helps to strengthen natural instincts and abilities, cautiously imparts high spiritual and moral qualities, directs them for maximum disclosure and strengthening of natural talents) [4, p. 61] in the changing social and economic conditions of the environment, lack of social competence-orientated programs for future primary school teachers in higher education, active teachers' age profile (about $65 \%$ of teachers are with the 20 year working experience or even longer, and there is an annual tendency of increasing), most of those teachers can be characterized as those who entered the stage of professional development "preservation" (aged 45-64 with the desire to maintain the status) and "decrease" (departure from professional life) [18].

We share the opinion of P. Khobzei, V. Kremen, O. Savchenko on the need for training, retraining and advanced training of teachers, which are factors of influence on the quality of teachers' education $[3 ; 11 ; 14]$ as it is of utmost importance to help teachers change their methods of work and adapt to modern requirements [3]. Taking these views into consideration, we share the opinion of P. Khobzei [14] who states that teachers' retraining is one of the challenges. It can be explained by the fact that they have stereotypical patterns of thinking and the process of professional burnout can be also observed. Low salaries paid to teachers hardly ever motivate (there have been certain changes recently, but insufficient enough to bring positive results in this sphere), teacher's salary is significantly lower than the average for all types of economic activity, taking into account rising inflation and war state (along with Israel, it is the lowest in the world; e.g. for comparison, in Poland - \$800, Turkey - \$1000, in Germany - more than 2500 euros, etc. granting rather high requirements) [8]. Along with the need to modernize, improve general and professional teacher's erudition, his or her efficiency, the development of human culture, moral and spiritual values, social activity and teacher's responsibility are of great importance. Thus, the development of social competence in postgraduate education that can quickly and flexibly respond to social changes, with all the necessary tools to create the appropriate conditions is quite relevant.

Primary school teachers' social competence $(S C)$ is represented as an "umbrella" structure. In such a construction the social component is considered as a stable orientation for cooperation, harmonious, fair agreement of interests permeating all the spheres of life, individualization, special form of various social relations. It consists of six components which are as follows: motivation and value, cognitive, activity, operational, personal and professional, reflexive. Given the fact that the volume of the scientific paper does not allow us to present a detailed analysis of each of the components, we have decided to focus on personal and professional one. It reflects the requirements for the proprium of personality (values, features of consciousness, characteristic of a particular person corresponding the convictions of an adult), seven aspects revealed in the successive stages of personality formation (according to G. Allport) [15], social responsibility to the country, society, parents, children, personal activity, emotional stability, tolerance, strong-willed control, empathy, sociability (the property of an individual, characterizing the extent of his or her inclusion into social micro-environment based on a combination of ability and the need to establish interpersonal contacts) in forming junior schoolchildren's SC, selfconfidence, and adequate self-esteem. Personal and professional component is also reflected in the development of younger student's proprium, in the formation of his or her responsibility on the basis of social, spiritual, moral, and economic choice of self; manifested in the ability to demonstrate an attractive personal role model of positive social and spiritual values in educational activities. This component is regarded as a two-dimensional entity having two constituents (emotional, professional). The first one describes the capacity for empathy; the second one - professional orientation of the individual.

The aim of the paper is to demonstrate the development results of the personal and professional component of primary school teacher's social competence in postgraduate educational process.

The following tasks should be solved:

1. To highlight the development of the personal and professional component of elementary school teacher's social competence at the ascertaining and control stages of the pedagogical experiment (using the previously developed criterionlevel toolkit), the experiment procedure.

2. On the basis of the obtained results to prove the wide possibilities of the system of postgraduate pedagogical education in order to create the necessary conditions.

\section{Research Methods}

In order to single out the first (emotional) constituent of the personal component, a method of testing was used, namely "Determination of Empathy Levels Inventory" by L. Mitina (hereinafter "DM \#9" - diagnostic method 9) [6, p. 51]. The respondents were asked to comment on 36 statements, attributing the following numbers to the comments: "I do not know" - 0, "no, never" - 1, "sometimes" 2, "often" - 3, "almost always" - 4, "yes, always" - 5. The statements concerned the needs, interests of the respondents with respect to the subject of reading, musical programs, painting, criticism, their emotional perception, attitude towards animals in childhood and to date, observation of their behavior, attitude towards parents, children, sick, elderly people, people who got into difficult, conflict situations, their own and other people's successes and failures, reflections on the relationship between small, older children and parents, younger children and peers, friends, and others, etc. Evaluation of the data was performed according to the following scale: high level - 82-90 points; sufficient level - 63-81 points; middle level - 37-62 points; low level - 36 points and fewer than 36 points, data evaluation was followed by the determination of average total test result 
for each group.

In order to evaluate the second (professional) constituent of personal-professional component of Primary school teacher's SC the questionnaire "Assessment of Teacher's Professional Orientation" was applied (the method suggested by Ye. Rogov, hereinafter "DM \#10" diagnostic method 10) [10]. It included the identification of such personality traits as: 1) sociability; 2) selfdiscipline; 3) focus on subjects. The respondents assessed typical or atypical character of their behavior according to each of these three factors, and then we calculated the initial score obtained by each of them, identified the level of their professional orientation development. The evaluation of data for each of the three factors was made according to the following scale: high level - 9-10 points; sufficient level - 7-8 points; middle level - 5-6 points; low level - 3-4 points, data evaluation was followed by the determination of average total test result for the control and experimental groups.

The method of simulation is used to develop a scientific and technological system and a structural and functional model of the complex prolonged development of elementary school teachers' SC in the system of postgraduate pedagogical education (SPPE), in particular, its personal-professional stage, aim, tasks, forms, methods of which are aimed at the development of the SC at the level of personal and professional component.

We have introduced some pedagogical measures (in experimental group) in the postgraduate process (formal, non-formal, informal) which is an integrated five-year long-term development of each component (including personal-professional) of SC in the system of postgraduate pedagogical education (hereinafter referred to as SPPE). They are focused on the growth of its effectiveness, specially created and tracked organizational and pedagogical conditions. The effectiveness of the above-mentioned system was verified in the educational process of six institutes and the twelve educational institutions (Odessa and Kryvii Rih). The observation of the process has made it possible to determine the relationship between the developed and theoretically grounded system of pedagogical measures and the result of pedagogical influence of SPPE on the development of the phenomenon under study.

The results on the person-professional component were processed using mathematical and statistical methods; the analysis of the effectiveness of the system of measures (analysis, synthesis, comparison, generalization, induction, deduction), aimed at solving scientific problem and eliminating contradictions, presenting the course and the results of research work was carried out.

The total number of participants in the ascertaining stage of pedagogical experiment was 649 primary school teachers. The control group (CG) was represented by 584 teachers, experimental group (EG) - by 65 . Based on these initial tests data (DM \#9) [6, c. 51]) we estimated total amount of points scored by each of the teachers, determined the level of their empathy development. According to the test scores all the respondents of the CG and EG were broken up into four level groups.

\section{Research Results}

The personal and professional component of SC reflects the ability of the teacher to create comfortable sociopsychological conditions for the self-realization of the students in the process of mastering practical components of educational branches and social activities.

Its first (emotional) constituent of the personal component aims to balance interpersonal relations between all participants of the educational process - teacher and students, their parents, between the members of the teaching staff of an educational institution (administration and colleagues). Developed empathy affects teacher's behavior and makes it socially conditioned, providing success in education of children.

Thus, it was found out that only a small number of participants in CG (3.4\%) and EG (1.5\%) showed a high level of empathic development, as indicated according to specified groups: sufficient level $-15.8 \%$ and $23.1 \%$; middle level $-79.8 \%$ and $72.3 \%$; low level $1 \%$ and $3.1 \%$. The results are presented in Table 1.

Table 1.

Levels of Development of the First (Emotional) Constituent of Personal and Professional Component of Primary School Teachers' Social Competence at the Ascertaining Stage of Pedagogical Experiment, \% $(P>0,05)$

\begin{tabular}{|c|c|c|c|c|c|c|c|c|}
\hline Levels & \multicolumn{2}{|c|}{ High } & \multicolumn{2}{c|}{ Sufficient } & \multicolumn{2}{c|}{ Middle } & \multicolumn{2}{c|}{ Low } \\
\hline Group & CG & EG & CG & EG & CG & EG & CG & EG \\
\hline DM \#9 & 3.4 & 1.5 & 15.8 & 23.1 & 79.8 & 72.3 & 1 & 3.1 \\
\hline
\end{tabular}

The second (professional) constituent of personal and professional component of primary school teacher's social competence refers to his or her professional focus. The results of its evaluation according to DM \#10 questionnaire [10] are as follows. It was found out that $2.1 \%$ of the respondents in the CG are highly communicative, there were no such respondents in the EG; sufficient level was demonstrated by $20.5 \%$ respondents in the CG and $20 \%$ in the EG; middle level $-43.2 \%$ and $44.6 \%$ - respectively; low $-33.6 \%$ and $30.8 \%$ respectively (Table. 2 , line 1 ). 
Table 2.

Levels of Development of the Second (Professional) Constituent of Personal and Professional Component of Primary School Teachers' Social Competence at the Ascertaining Stage of Pedagogical Experiment, \% (P>0,05)

\begin{tabular}{|c|c|c|c|c|c|c|c|c|c|}
\hline \multirow{2}{*}{\multicolumn{2}{|c|}{$\begin{array}{l}\text { Levels } \\
\text { Group }\end{array}$}} & \multicolumn{2}{|c|}{ High } & \multicolumn{2}{|c|}{ Sufficient } & \multicolumn{2}{|c|}{ Middle } & \multicolumn{2}{|c|}{ Low } \\
\hline & & $\mathrm{CG}$ & EG & $\mathrm{CG}$ & $\mathrm{EG}$ & $\mathrm{CG}$ & EG & $\mathrm{CG}$ & $\mathrm{EG}$ \\
\hline \multirow{3}{*}{ 主 } & 1 & 2.7 & 4.6 & 20.5 & 20 & 43.2 & 44.6 & 33.6 & 30.8 \\
\hline & 2 & 2.1 & - & 18.5 & 15.4 & 42.8 & 35.4 & 36.6 & 49.2 \\
\hline & 3 & 6.2 & 9.2 & 14.4 & 21.6 & 38.3 & 32.3 & 41 & 36.9 \\
\hline \multicolumn{2}{|c|}{ Mean values } & 3.7 & 4.6 & 17.8 & 19 & 41.4 & 37.4 & 37.1 & 39 \\
\hline
\end{tabular}

So, despite the fact that in their professional activity teachers constantly have to communicate with students, their parents, peers, school administration, etc., $1 / 3$ respondents due to communication overload tend to avoid it or not to show interest, that can indicate the first signs of burnout (emotional exhaustion), therefore such primary school teachers are almost unable to realize high communicative function on the basis of generally accepted social and pedagogical requirements.

According to the survey aimed at identifying such properties as self-discipline, we have found out that only $2.1 \%$ of the teachers of the CG had a high level of such characteristics; and the respondents in the EG have not demonstrated the high level. The sufficient level has been found in $18.5 \%$ of the respondents in the $\mathrm{CG}$ and $15.4 \%$ in the EG; average level $-42.8 \%$ and $35.4 \%$ respectively; low level $-36.6 \%$ and $49.2 \%$ respectively (Table 2 , line 2).

Analyzing the research outcomes, it should be noted that most elementary school teachers do not show significant desire to intensify their professional activities. Very often, when they experience difficulties, they cannot do their best to realize certain functions, such as executive, mobilizing or organizing. This is the second indicator of emotional burnout. Incidentally, the case can be explained by the age of the teaching staff.

Regarding the focus on the subjects, it has been determined that only $6.2 \%$ of teachers in the CG and $9.2 \%$ in the EG show a high level of the maturity of such characteristics; sufficient level $-14.4 \%$ and $21.6 \%$ respectively; average level $-38.3 \%$ and $32.3 \%$ respectively; low level $41 \%$ and $36.9 \%$ respectively (Table. 2 , line 3 ), therefore, a great number of teachers show no significant interest in their professional activities, they are usually unable to implement constructive, methodical, educational and orientation professional functions. It results in the third feature personal burnout. In this case we note the third indicator of burnout - personal burnout. This set of burnout indicators is aggravated with stressful situations due to the existing military conflict and related economic problems. Generalized data that reflect the development of the second (professional) constituent of personal and professional component of teachers' social competence are presented in Table 2 (line 3).

Combined results of the development of personal and professional component of primary school teachers' social competence at the ascertaining stage of pedagogical experiment (according to four previous surveys) are set out in Table 3 .

Table 3.

Levels of Development of Personal and Professional Component of Primary School Teachers' Social Competence at the Ascertaining Stage of Pedagogical Experiment, \% (P>0,05)

\begin{tabular}{|l|l|l|l|l|l|l|l|l|}
\hline Levels & High & Sufficient & Middle & Low \\
\hline Group & CG & EG & CG & EG & CG & EG & CG & EG \\
\hline DM \#9 & 3.4 & 1.5 & 15.8 & 23.1 & 79.8 & 72.3 & 1.0 & 3.1 \\
\hline DM \#10 & 3.7 & 4.6 & 17.8 & 19 & 41.4 & 37.4 & 37.1 & 39 \\
\hline Mean values & 3.5 & 3.1 & 16.8 & 21 & 60.6 & 54.9 & 19.1 & 21 \\
\hline
\end{tabular}

Determining the average index, magnitude of error and quadratic deviation, calculation of Student's t-test on the basis of generally accepted formula for independent samples has made it possible to establish the relationship between the arithmetic mean of the values of the control and experimental groups. If the resulting value of t-test does not exceed the threshold value (according to the table), the hypothesis of equality of the initial results proves correct. If a found criterion index exceeded the tabular, the null hypothesis of equality of the two arithmetic variables CG and EG is rejected, and the difference is considered statistically significant at the significance level $\mathrm{a}=0.05$.
Checking the data authenticity allowed to note the lack of significant differences between the arithmetic mean of the values in the CG and EG (t-calc. (1.39) <t-table. (1.96)). It demonstrated their homogeneity $(\mathrm{P}>0.05)$. Thus, the homogeneity of their composition is confirmed by the indices of the six components of social competence, including personality-professional, registered in the groups (t-factor (1.32) <t-tabl. (1.96); P> 0.05).

The results showed a significant social need for socially competent primary school teachers, the relevance of this phenomenon for the teacher, the development of his or her social and professional abilities in the formation of younger 
student's SC. It was also found out that the development of various components is unbalanced (the lowest results for the levels were stated regarding the cognitive and personality-professional components) (Table 4). And it has become the basis for continuing the pedagogical experiment.
It also stresses the importance of the need for special attention to the choice of means of influence, the creation of organizational and pedagogical measures in SPPE requires prolonged experimental verification.

Table 4.

Combined Results of the Development of Primary School Teacher's Social Competence concerning Cognitive Component (CC) and Personal-Professional Component (PPC) at the Ascertaining Stage of Pedagogical Experiment (Representing Six-Component Structure), \%

\begin{tabular}{|c|c|c|c|c|c|c|c|c|}
\hline Level & \multicolumn{2}{|c|}{ High } & \multicolumn{2}{c|}{ Sufficient } & \multicolumn{2}{c|}{ Middle } & \multicolumn{2}{c|}{ Low } \\
\hline Group & CG & EG & CG & EG & CG & EG & CG & EG \\
\hline CC & - & 3.1 & 8.6 & 6.2 & 46.2 & 44.6 & 45.2 & 46.1 \\
\hline PPC & 3.5 & 3.1 & 16.8 & 21 & 60.6 & 54.9 & 19.1 & 21 \\
\hline
\end{tabular}

Note: 1. CC - Cognitive Component, PPC - Personal-professional Component of Primary School Teacher's Social Competence. 2. (t-calc. $(2,71)>$ t-table. $(1,96)) ; \mathrm{P}<0,05$.

\section{Discussion}

The content of the formative stage of the pedagogical experiment was based also on the data obtained, in particular, on the development of the personal and professional component of the phenomenon under study. These results actualized the need for the use of burnout diagnostics in the process of our research and during the break periods, the subsequent mandatory involvement in various trainings, the use of self-regulation techniques for effective "resetting' of stress, and the restoration of work capacity, which is taken into account, given that the syndrome can be collapsed at any stage, but the first stage is the most "favorable".

Here is one of the exercises, a game to avoid emotional burnout, identification of existing behavior and thinking stereotypes: "At home I often...", At school I often..." or "At home I never ....", "At school I never ....". A teacher divides a sheet of paper into two columns and composes two lists of characteristics, traits, attitudes, associations, actions (as many as possible). The statements were analyzed according to the parameters of similarity, dissimilarity, opposite or common patterns, traits qualities in different situations; lack of common features; teachers answer the questions: "Which list was easier to make, which one is longer?", "What do you think concerning significant differences in two lists?" and so on. Discussions in the form of pedagogical game as debate (public dispute in order to develop new knowledge and beliefs, the deepening of understanding of new theoretical positions, overcoming false judgments, correction and refinement of conventional notions of teachers' skills and enabling them to express their thoughts logically, enrich their own opinions with educational theory to analyses and compare different views, the ability to find evidence and reinforce their conclusions and communication. Relaxed, friendly relations between the group members gave them a new opportunity to look at the situation from another point of view, to consider the possible ways and means of preventing further emotional burnout. Similar in essence, is a method of "T-chart", which was used at creative group workshops to identify positive and nega- tive actions and phenomena, in the formation of younger students' social competence in particular.

The psychological stress of the teacher is also taken into account, which is further complicated by the social situation in the country. That is why during the classes one of the goals is the creation of psychologically comfortable working conditions based on spiritual interaction, social partnership, co-creation (which is also important in the context of the Concept of the new Ukrainian school). In order to implement abovementioned into real-life practices, we suggest social reflection, pauses of psychological relaxation (observing prepared presentations, video clips, which contributed to psychological, emotional relaxation, opening of spiritual characteristics). In the presentations they used associative photos, often humorous, which, in combination with the awakening of the emotional sphere, contributed to the understanding of complex scientific ideas. The motivation of teachers to create the same product was successful: the audience revealed their creative potential, demonstrated understanding of the topic under study. They understood the benefits of the media product they produced for both the creative group and directly for the educational process of elementary schools, extracurricular activities, and the development of junior schoolchildren. Satisfaction of the personal social and professional needs of teachers in psychological support, gaining social and psychological competence, skills of psychological self-support under conditions of crisis (many teachers have their relatives in the area of antiterrorist operation, there are families with wounded or dead members), support of children and their parents was carried out during meetings with the crisis psychologist, acquainting the students with the concept of "psychological crisis", its three types (crisis of development, loss, traumatic crisis), reasons for its occurrence and four consecutive stages of development. Teachers had an opportunity to learn how to distinguish signs of approaching crisis, its irresolution, complex symptoms of grief, to learn about the possibilities of psychological services in solving urgent and long-term problems vital to life, new directions in psychological practices, aimed at 
normalizing the mental state of people who suffered from the impact of natural or man-made disasters. Psychologist's advice on changes, instructions to the peaceful population during the information warfare were discussed. The main accent was placed on the idea that any war would end, and therefore, one must always remain a human being. At the practical lesson, the students considered a problematic issue about the advantages of psychotherapy; they became familiar with strategies for constructive stress relief, such as relaxation, balance of desires and opportunities, self-control, time management, relationships with people, help and support, reflexotherapy in periods of stress, depression; proper nutrition, exercises. Advice on the ways of assistance and selfassistance during crisis, stressful situations, negative emotional states, involving the techniques of speaking, writing letters, helping others, dreaming, making gifts, etc. were considered rather helpful. Exercise "Air balloons", relaxation techniques, self-massage, visualization of self-persuasion became useful in getting rid of the usual stress reactions, calm perception of situations that usually cause stress. This became an additional motiva- tion for the teachers' self-development, a manifestation of the formation of a reflexive environment. Feedback from listeners on the basis of survey results, interviews, questionnaires confirmed qualitative shifts in the development of the SC when they mastered the knowledge and obtained skills in class and in the process of self-education through on-line libraries, chats, video chats, video conferences, etc., study of methodological materials, prepared by teachers for each lesson, application of skills acquired in the practice of teaching and social activities. All this provided for the complexity and sustainability of the development of the SC. An important role in this was played by pedagogical technologies and conditions, the characteristics of which require special attention in separate publications.

For a better understanding of the course of the experiment, we characterize the personality-professional stage of the structural and functional model of the complex prolonged development in relation to the personalityprofessional component of the SC of the elementary school teacher in SPPE (Table 5).

Personal-Professional Stage of the Structural and Functional Model of the

Complex Prolonged Development in Relation to the Personal-Professional Component of Social Competence in the System of Postgraduate Pedagogical Education

Table 5 . The content of the stage

\begin{tabular}{|l|l|}
\hline \multicolumn{2}{|c|}{ The content of the stage } \\
\hline Aim & $\begin{array}{l}\text { The development of SC, disclosure of the potential of the teacher's personality, social orientation of } \\
\text { the system of motives and values }\end{array}$ \\
\hline Tasks & $\begin{array}{l}\text { Disclosure of internal self-identification of teachers (personal, social-professional identity). Self- } \\
\text { cognition (purpose in life and profession, resources and opportunities for its realization, my mission on } \\
\text { earth, the position of goodness, love, freedom and responsibility, stability in standard and non-standard } \\
\text { situations, personal involvement in the profession (I-professional values). Orientation on self- } \\
\text { inducement for further social and professional development }\end{array}$ \\
\hline Forms & $\begin{array}{l}\text { Common forms (lectures: discussions, presentations, problems solutions, interactive, trainings, educational } \\
\text { and educational games, consultations, conferences, chat rooms and on-line, creative papers defence) and } \\
\text { specific (work in discussion, creative, subject microgroups with socially oriented topics, psycho-thrills, } \\
\text { psychotrainings, media conferences, media forums, elements of research, etc. }\end{array}$ \\
\hline Methods & $\begin{array}{l}\text { Portfolio method, social and educational situations method, art-pedagogical technologies, art therapy, } \\
\text { fairy-tale therapy, teaching and educational games, methods of creative development, personal devel- } \\
\text { opment trainings, methods of associations and tendencies, a side view, a change in the system of val- } \\
\text { ues, situational tasks, autotraining, relaxation }\end{array}$ \\
\hline Results & $\begin{array}{l}\text { The development of the SC at the level of personal component: the individual style of social and peda- } \\
\text { gogical activity, the maximum use of their own internal resources and possibilities of the environment } \\
\text { for the further development of mechanisms of adaptation self-development, self-regulation, self- } \\
\text { realization }\end{array}$ \\
\hline
\end{tabular}

It should be noted that the above described model in accordance with the vision of the SC as a generalization concept for a set of competencies that are reflected in the directions of its activity made it possible to set up in the postgraduate process the activity on the development of the personal-professional component. It enables to present its prolongation and elements step by step, level by level, and at the same time in an integrated way, starting from the planned courses (regarding attestation).

So, let us highlight the measures planned by the structural-functional model of the complex prolonged development of social competence of elementary school teachers in SPPE, namely, the personal-professional stage.

In the process of interaction during lectures, in practical interaction in relation to the problematic themes "Social Competence of the Elementary School Teacher as a Condition for the Introduction of Innovative Technologies in the Educational Process of the Ministry of Education and Science", "Pedagogical Skills of Elementary 
School Teacher", "Media Education" (2 academic hours of lectures and practical classes), etc. teachers had the opportunity to renew (get new) knowledge about social competence, including its personal-professional component, characteristics and stages of development of the personality of a modern teacher, his or her professionalism, skills, competence, etc.

The selection of teaching methods was based on psychological achievements in terms of: supporting the personality in the learning process, the regularities and styles of learning in the group, the perception of information by the person (according to P. Honey and A. Mumford [16]); five types of socio-cultural information (according to V. Lugovyi) [5, p. 11], types of intelligence (abstract, concrete, social, emotional), individual characteristics, group dynamics [9], structural components of personality, role-based concept (J. Mead, R. Linton T. Parsons, etc. [17]), three-level hierarchical system of social role, five main characteristics of the role of a person (emotionality, way of receiving, scale, formalization, motivation), disclosure of their content in accordance with social and professional activities. Each practical training in the postgraduate process contained experience, observation and reflection, the formation of abstract concepts and generalizations, the verification of the results of the operation of these concepts in new conditions and situations (stages by K. Levin) [16], namely, training was based on the principle of a spiral.

In order to develop personal and professional component of the SC in accordance with the model the ability to socially fill the knowledge of subjects with the invariant, variation part of the curriculum of the elementary school, apply socially oriented knowledge, constantly master these skills improving them in the competition were worked out. Observing others in situations that are specially created and socially enriched, teaching others, self-learning made it possible to act in different roles (a teacher, a student, a market participant involved in legal, political, social and other relationships) contributed to mutual spiritual enrichment in the team, exchange of professional, social and life experiences.

Self-confidence enhancements (J. Porsche, J. Niederer) as a means of verbal support, recognition for achievements, matching of competencies to the level of training, adjustment through poetry, quotations, examples, provision of the necessary resources for achieving goals, organization of mutual support in the group [12], as well as trainings on psychological support in socially disorganized environment were considered to be appropriate and efficient.

Focusing on the experience of a teacher as a source of teaching, a teacher in the natural and specially created post-graduate process situations, facilitated the identification, use of social, life, and pedagogical experience (positive / negative), connection with the educational process. This approach was a model for developing the skills of the teachers themselves to focus on the social experience of students, to include it in the content of various subjects, specific learning tasks with a well-known baggage of social experience, to encourage students to exchange social experience regarding the content of educational tasks, events taking place in the society, use it to ensure motivation for learning regarding the social needs of students, the choice of a relevant direction of educational work in a particular situation, to treat any experience as a way of social enrichment, to find time to help schoolchildren learn and apply their skills.

Taking into account the fact that the teacher's ability to create favorable socio-psychological conditions for students' personality self-realization characterizes the personal-professional component, the elements of the model of the development process of the SC were the skills that could ensure the success of this activity, namely: to encourage team work and cooperation; to show ethical behavior and honesty in relationships; give clear instructions; have and demonstrate a sense of humor; avoid protective behavior; treat students with dignity and respect, recognize their individual abilities; use time effectively, providing additional value of time spent in class, use personally oriented, individual and environmental approaches, set up feedback. That is why special measures were used to develop skills to plan educational objectives regarding the areas of immediate development, individual characteristics, own pace of development of every student, to determine their individual characteristics, to use the latter for the implementation of educational tasks, the choice of forms of study (work in small groups, work in pairs, etc.), decision-making in relation to educational tasks based on the recommendations of the 0curricula, as well as own observations on children and their assessment, the use of surveillance to track individual progress of every student in planning the expected results of the educational environment, social environment fundraising aimed at fostering SC of primary schoolchildren.

The model is also aimed at developing the ability to create a learning environment free of prejudices and stereotypes, focused on the values and principles of democracy, the structure of civil society, the rules of law. The attention was also paid to the importance (in the context of decentralization of the state) of understanding of the type of socio-cultural situation where an educational institution is located, the ability of teachers to attract resources of the socio-cultural environment, the impact on "restoration of their health", the use of media resources, the use of elements of research activities as manifestation of creativity. Teachers learned to model a pedagogical process oriented towards education for social justice; design a sense of understanding and forgiveness if an incident occurs; encourage recognition of the diversity of every member of the team, respect, tolerant methods of decision-making; create conditions and motivate students for their conscious choice in school life, society, which accordingly initiated the conditions for the development of responsibility for the choice made; take into account the contribution of every student in joint matters, in particular 
social content, to stimulate cooperative learning, in which the students are taught on the basis of cooperation and self-management. Teachers developed their skills of defining a common social purpose of learning, the content of group work, drawing up plans; simulation of active participation of everyone in the group work, selfmanagement and communication of students, their mutual evaluation, constructive feedback. All these skills are the components of the model (reflected in the structure, aim, tasks, extensive system of classes, predominance of practical, training forms of work).

Given the understanding of social competence as the adequacy and efficiency of solving various problem social situations, the process of the development of teachers SC in the SPPE became problematic, followed by interdisciplinary modules in the joint activity of teachers and students with the active participation of the latter. Introduction of prolonged forms of support (information, counseling during the course of training, in the intercourse period, as well as the permanent updating of the teaching materials of lectures, creative groups, seminars (conducted for five years continuously), free access to them (Internet resources of the institute such as ZapoWiki, blogs of the Department of Innovative Educational Technologies, teachers who worked in this field, laboratories on the issue of introducing socio-cultural approach) at the beginning of education, in its process, on mastering the material, as well as self-study as an opportunity for teachers to choose forms of study, the level of complexity of tasks are characteristic of the updated model of the development of the elementary school teachers' SC.

It is noteworthy that the post-graduate process of the development of the personal-professional component of the SC is influenced by the peculiarities of its structure, taking into account the results of the students' reflection on the results of the previous operational-technological stage.

Effectiveness of the influence of the chosen pedagogical factors on the development of each of the components of teacher's SC was verified during the control phase of the pedagogical experiment. All in all, 181 participants took part in the experiment (116 teachers comprised control groups and 65 teachers - experimental groups). The level of the development of personalprofessional component was evaluated accordingly to both of its constituents. The test results (DM \#9) [5] concerning the development of the first (emotional) constituent show that only a small number of participants in $\mathrm{CG}$ $(4.3 \%)$ and EG $(10.8 \%)$ demonstrate a high level of empathic development, as indicated according to specified groups: sufficient level $-23.3 \%$ and $26.1 \%$; middle level $-72.4 \%$ and $63.1 \%$. We should emphasize that no cases of low level have been found. The comparison of the research data concerning the development of the first (emotional) constituent of personal and professional component of primary school teachers' $\mathrm{SC}$ in $\mathrm{CG}$ and $\mathrm{EG}$ showed their significant difference $(\mathrm{P}<0,05)$ in favor of the latter (Table 6).

Table 6

Levels of Development of the First (Emotional) Constituent of Personal and Professional Component of Primary School Teachers' Social Competence at the Ascertaining Stage of Pedagogical Experiment, \% $(P>0,05)$

\begin{tabular}{|c|c|c|c|c|c|c|c|c|}
\hline Levels & \multicolumn{3}{|c|}{ High } & \multicolumn{2}{c|}{ Sufficient } & \multicolumn{2}{c|}{ Middle } & \multicolumn{2}{c|}{ Low } \\
\hline Group & CG & EG & CG & EG & CG & EG & CG & EG \\
\hline DM \#9 & 4.3 & 10.8 & 23.3 & 26.1 & 72.4 & 63.1 & - & - \\
\hline
\end{tabular}

Comparing the initial and final results of the development of the first (emotional) constituent of personal and professional component in the $\mathrm{CG}$ and the EG allows us to note their positive dynamics in the EG (respectively $1.5 \%$ and $10.8 \%$ - high level, $23.1 \%$ and $26.1 \%$ - sufficient, $72.3 \%$ and $63.1 \%$ - middle, $3.1 \%$ and $0 \%-$ low), while in the CG there was only a slight tendency to improvement (respectively $3.4 \%$ and $4.3 \%$ - high level, $15.8 \%$ and $23.3 \%$ - sufficient, $79.8 \%$ and $72.4 \%$ - middle, $1 \%$ and $0 \%$ - low).

In order to determine the maturity of the second (professional) constituent of personal social competence questionnaire DM \#10 [10] was used. Based on the survey results for each of the three factors (sociability, self- discipline, focus on subjects) that characterize the professional component of the personal component we determined $2.6 \%$ of the CG and $12.3 \%$ of the EG respondents to have high level of development of sociability; sufficient level was demonstrated by $25.9 \%$ and $41.5 \%$ respectively; average by $43.1 \%$ and $35.4 \%$ respectively; low by $28.4 \%$ and $10.8 \%$ respectively. Comparing the results in the CG and the EG concerning sociability development, which is one of the factors of the development of the second (professional) constituent of personal and professional component of SC demonstrated their significant difference in favor of the latter $(\mathrm{P}<0,05)$, as reflected in Table 7 (line 1). 
Table 7.

Levels of the Development of the Second (Professional) Constituent of Personal and Professional Primary

School Teachers' Social Competence at the Control Stage of Pedagogical Experiment, \% $(P<0,05)$

\begin{tabular}{|c|c|c|c|c|c|c|c|c|c|}
\hline \multirow{2}{*}{\multicolumn{2}{|c|}{$\begin{array}{l}\text { Levels } \\
\text { Group }\end{array}$}} & \multicolumn{2}{|c|}{ High } & \multicolumn{2}{|c|}{ Sufficient } & \multicolumn{2}{|c|}{ Middle } & \multicolumn{2}{|c|}{ Low } \\
\hline & & CG & $\mathrm{EG}$ & $\mathrm{CG}$ & $\mathrm{EG}$ & $\mathrm{CG}$ & EG & $\mathrm{CG}$ & $\mathrm{EG}$ \\
\hline \multirow{3}{*}{$\sum_{\Delta} \frac{0}{\#}$} & 1 & 2.6 & 12.3 & 25.9 & 41.5 & 43.1 & 35.4 & 28.4 & 10.8 \\
\hline & 2 & 3.4 & 10.8 & 18.2 & 41.6 & 56 & 27.7 & 22.4 & 19.9 \\
\hline & 3 & 8.6 & 6.2 & 18.1 & 32.3 & 40.5 & 46.1 & 32.8 & 15.4 \\
\hline \multicolumn{2}{|c|}{ Mean values } & 4.9 & 9.8 & 20.7 & 38.4 & 46.5 & 36.4 & 27.9 & 15.4 \\
\hline
\end{tabular}

Monitoring sociability dynamics of primary school teachers during the pedagogical experiment in EG, we should note positive changes between the initial and final results $(4.6 \%$ and $12.3 \%$ - high level, $20 \%$ and $41.5 \%-$ sufficient; $44.6 \%$ and $35.4 \%$ - middle, $30.8 \%$ and $10.8 \%$ - low). The participants of the CG demonstrated a slight change between output and input results, slower development $(2.7 \%$ and $2.6 \%$ - high level, $20.5 \%$ and $25.9 \%$ sufficient, $43.2 \%$ and $43.1 \%$ - middle, $33.6 \%$ and $28.4 \%$ - low, respectively).

As for self-discipline, the control experimental stage showed the following results: high level $-3.4 \%$ of the CG and $10.8 \%$ of the EG; sufficient $-18.2 \%$ and $41.6 \%$ respectively; middle $-56 \%$ of respondents of the CG and $27.7 \%$ respectively; low $-22.4 \%$ and $19.9 \%$, respectively.

The comparison of the results in the CG and the EG at the control stage concerning the development of teachers' self-discipline, which is one of the factors of the development of the second (professional) constituent of personal and professional component of social competence, showed significant difference in favor of the latter ( $\mathrm{P}<0.05)$, which is demonstrated in table 7 (line 2).

The results of monitoring the dynamics of teachers' self-discipline during the experiment in EG enables us to note positive changes of the initial results compared to the final (respectively $0 \%$ and $10.8 \%$ - high level, $15.4 \%$ and $41.6 \%$ - sufficient; $35.4 \%$ and $27.7 \%$ - middle, $49.2 \%$ and $19.9 \%$ - low). The CG demonstrated slight and slow changes (respectively $2.1 \%$ and $3.4 \%$ - high level, $18.5 \%$ and $18.2 \%$-sufficient, $56 \%$ and $43.1 \%$ - middle; $36.6 \%$ and $22.4 \%-$ low).

The control experimental stage also demonstrated the following results of "focus on the subjects" development: high level $-8.6 \%$ of the CG and $6.2 \%$; sufficient $-18.1 \%$ and $32.3 \%$ respectively; middle $-40.5 \%$ and $46.1 \%$ in the EG respectively; low in $32.8 \%$ and $15.4 \%$ respectively (table 7, line 3).

Comparing the generalized results of the $\mathrm{CG}$ and the EG at the control stage of pedagogical experiment considering the development of "teachers' focus on their subjects" we can note a significant difference in favor of the latter $(\mathrm{P}<0.05)$, as described in Table 7 (bottom line).

Monitoring the dynamics of 'teacher's focus on subjects" throughout the experiment in EG, we can note positive changes comparing input and output results (respectively $9.2 \%$ and $6.2 \%$ - high level, $21.6 \%$ and $32.3 \%$ - sufficient; $32.3 \%$ and $46.1 \%$ - middle, $36.9 \%$ and $19.9 \%$ - low). In the CG there were slight and slow changes, respectively $6, .2 \%$ and $8.6 \%$ - high level; $14.4 \%$ and $18.1 \%$ - sufficient; $38.3 \%$ and $40.5 \%$ - middle; $41 \%$ and $32.8 \%$ - low (the levels of the development of personal and professional component of teachers' social competence at the control stage of pedagogical experiment are shown in Table 8). In EG we can observe slight positive changes in the development of personal and professional component that is proved by the differences between their average values in CG and EG (T-calc. (2.51)> t-table. (1.96))

Levels of the Development of Personal and Professional Component of Primary School

Table 8

Teachers' Social Competence at the Control Stage of Pedagogical Experiment, \% $(P<0.05)$

\begin{tabular}{|l|l|l|l|l|l|l|l|l|}
\hline Levels & \multicolumn{2}{l}{ High } & \multicolumn{2}{l|}{ Sufficient } & \multicolumn{2}{l|}{ Middle } & \multicolumn{2}{l|}{} \\
\hline Group & CG & EG & CG & EG & CG & EG & CG & EG \\
\hline DM \#9 & 4.3 & 10.8 & 23.3 & 26.1 & 72.4 & 63.1 & - & - \\
\hline DM \#10 & 4.9 & 9.8 & 20.7 & 38.4 & 46.5 & 36.4 & 27.9 & 15.4 \\
\hline Mean values & 4.6 & 10.3 & 22 & 32.2 & 59.5 & 49.8 & 13.9 & 7.7 \\
\hline
\end{tabular}

Comparing the initial and final results of the study concerning the levels of the development of personal and professional component of social competence in the CG and the EG enables us to note positive dynamics in the EG (respectively $3.1 \%$ and $10.3 \%$ - high level, $21 \%$ and $32.2 \%$ - sufficient, $54.9 \%$ and $49.8 \%$ - middle, $21 \%$ and $7.7 \%$ - low), while the CG there was only a tendency towards improvement (respectively $3.5 \%$ and $4.6 \%$ - high level, $16.8 \%$ and $22 \%$-sufficient, $60.6 \%$ and $59.5 \%-$ middle, $19.1 \%$ and $13.9 \%$ - low). The comparison of the arithmetic average of generalized results of the $\mathrm{CG}$ and the EG demonstrates their significant differences ( $t$-calc. (2.71)> t-table. (1.96)), indicating significant changes that occurred in the development personal and professional component $(\mathrm{t}$-calc. $=2.51)$ during the formative stage of pedagogical experiment. 


\section{Conclusion}

1. The results of the development of the personal and professional component of primary school teachers' SC obtained as a result of the pedagogical experiment, are the lowest compared to the development of other components of SC, and confirmed the necessity of the development of this phenomenon as a social and personal need. The suggested innovative approach to the development (we developed and implemented a structural and functional model, organizational and pedagogical measures as components of the technology of the complex prolonged development of primary school teachers' social competence in the system of postgraduate pedagogical education. The results of the control phase, their comparison to the data of the ascertaining stage revealed certain significant

\section{REFERENCES}

1. Honcharenko, S. U. (2011). Ukraïnskii pedagogichnii entsiklopedichnii slovnik [Ukrainian Encyclopedic Dictionary]. $2^{\text {nd }}$ edition. Rivne: Volinski oberehi [in Ukrainian].

2. Doctorovich, M.O. (2009). Sotsialna kompetentnist yak naukova problema [Social competence as a scientific problem]. Psykholohiya i suspilstvo - Psychology and society, 3, 144-147 [in Ukrainian].

3. Kremen V.H. (2016). Perekhodiachy do dvanadtsiatyrichky, neobkhidno suttievo zminyty nashu shkolu [Shifting to 12-year secondary school]. Osvita Ukraiiny - Education of Ukraine, 4 [in Ukrainian].

4. Kudin, V. A. (2006). Obrazovanie $v$ sudbakh narodov (Didaktika novogo vremeni) [Education in Peoples Fates (The Didactics of New Era)]. Kyiv: PP «EKMO». [in Russian].

5. Lugovyi, V. I. (2014). Teoretiko-metodologicheskikh zasadi zalizhnosti metodiv i zadobiv otsinuvannya vid zmistu competences [Theoretical and methodological principles of the dependence of methods and means of evaluation on the content of competencies]. Kontseptualno-metodolohichni osnovy proektuvannya metodiv $i$ zasobiv diahnostyky osvitnikh rezultativ $u$ vyshchykh navchalnykh zakladakh: monohrafiya - Conceptual methodological bases of projecting methods and means of evaluating education outcomes at higher educational institutions. (pp. 7-15). V. I. Luhovoho, O. H. Yaroshenko (Ed.). Kyiv: Pedahohichna dumka [in Ukrainian].

6. Mitina, L. M. (2005). Professionalnaia deiatelnost $i$ zdorove pedagoga [Teacher's Professional activity and Health]. Moscow: Akademiia [in Russian].

7. Nova ukraiinska shkola: kontseptualni zasady reformuvannia serednoii shkoly. [New Ukrainian School: Conceptual Principles of Secondary School Reforming. (2016). Retrieved from: http: //mon.gov.ua/activity/education/zagalna-serednya/ua-sch2016/konczepcziya.html [in Ukrainian].

8. Zdioruk, C. I., Karpenko, M. M., Bogachevska, I. V. (2013). Osvita i nauka v innovatsiinomu rozvytku suchasnoii Yevropy [Education and Science in Innovational Develop- changes that occurred during the process of forming stage of our pedagogical experiment.

2. The obtained results confirmed the dependence between the developed and theoretically grounded system of pedagogical measures and the consequence of the pedagogical influence of postgraduate education on the development of the phenomenon under study, the effectiveness of the scientific and technological system of the complex prolonged development of teachers' social competence, great possibilities of the system of postgraduate pedagogical education for the creation of the necessary conditions that give grounds to recommend it for practical application both in postgraduate education and in primary school teachers' training.

ment of Modern Europe]. Kyiv: NISD. Retrieved from: http: //www.euroosvita.net/prog/data/attach/2987/ nauka_osv.pdf [in Ukrainian].

9. Platonov, Yu. P. Sotsialnyye roli i sotsial'nyye statusy [Social roles and social statuses]. - Retrieved from http: http://www.elitarium.ru/-

2007/03/23/socialnye_statusy_i_socialnye_roli.html. [in Russian].

10. Rogov, E. I. (1998). Uchitel kak obieekt psikhologicheskogo issledovaniia [A Teacher as an Object of Psychological Research]. Moscow: Gumanit. izd. tsentr VLADOS [in Russian].

11. Savchenko, O. Ya. Yakist pochatkovoi osvity: sutnist i chinniki vplivu [The Quality of Primary Education: the Essence and Impact Factors]. Naukovyi visnyk MDU imeni V.O. Sukhomlynskogo - Scientific bulletin, 1 (33), 915. «Pedahohichni nauky». Retrieved from: http: //mdu.edu.ua/spaw2/uploads/files/4_8.pdf [in Ukrainian].

12. Stan trenerom dlya vsekh $i$ vo vsem [Become a coach for everyone and everything]. (2005). Rostov n/D : Fenyks [in Russian].

13. Sukhomlinskii, V. A. (1979). Izbrannye proizvedeniia [Selected Works]. Kyiv: Rad. shkola [in Russian].

14. Khobzei, P. (2015). Yakist osviti u shkoli zalezhyt vid uchytelia, zmistu ta navchalnogo seredovyshcha [The Quality of School Education Depends on the Teacher, Content and Environment]. Retrieved from: http: //mon.gov.ua/usi-novivni/novini/2015/11/10/pavlo-xobzejyakist-osviti-v-shkoli-zalezhi/[in Ukrainian].

15. Frager, R., Fadiman, J. Glossary of "personality \& personal growth". Retrieved from: http:// vocabulary.ru/dictionary/36. [in English].

16. Kolb, D. A. (1984). Experiential learning: Experience as the source of learning and development. Englewood Cliffs. N.J. : PrenticeHall, Inc. [in English].

17. Linton, R. (1936). The study of a man: an Introduction. Paperback. Prentice Hall. [in English].

18. Super, D. E., et al. (1957). Vocational Development: a Framework of Research. New York [in English]. 


\section{ЛІТЕРАТУРА}

1. Гончаренко С. У. Український педагогічний енциклопедичний словник / С. У. Гончаренко. - 2-ге вид., доп. і випр. - Рівне : Волинські обереги, 2011.$552 \mathrm{c}$.

2. Докторович М. О. Соціальна компетентність як наукова проблема / М. О. Докторович // Психологія і суспільство. - 2009. - № 3. - С. 144-147.

3. Кремень В.Г. Переходячи до дванадцятирічки, необхідно суттєво змінити нашу школу / В.Г. Кремень // Освіта України, 2016. - №4.

4. Кудин В. А. Образование в судьбах народов (Дидактика нового времени) / В.А. Кудин. - Киев: ПП «ЭКМО», 2006. - $192 \mathrm{c}$.

5. Луговий В. І. Теоретико-методологічні засади залежності методів і засобів оцінювання від змісту компетентностей / В.І.Луговий // Концептуально-методологічні основи проектування методів і засобів діагностики освітніх результатів у вищих навчальних закладах : монографія / за заг. ред. В. І. Лугового, О. Г. Ярошенко. - Київ : Педагогічна думка, 2014. - С. 7-15.

6. Митина Л. М. Профессиональная деятельность и здоровье педагога / Л. М. Митина. - М.: Академия, 2005. -368 c.

7. Нова українська школа: концептуальні засади реформування середньої школи: [Електронний ресурс]. - - Режим доступу: http://mon.gov.ua/activity/education/zagalna-serednya/uasch-2016/konczepcziya.html (in Ukrainian)

8. Освіта і наука в інноваційному розвитку сучасної Європи [Електронний ресурс] : Аналітична доповідь // С. І. Здіорук, М. М. Карпенко, І. В. Богачевська, С. О. Зубченко, А. Ю. Іщенко, В. С. Лозовий. - Київ : НІСД, 2013.- Режим доступу : http://www.euroosvita.net/prog/data/attach/2987/ nauka_osv.pdf

9. Платонов Ю. П. Социальные

роли

и социальные статусы [Электронный ресурс] / Ю. П. Платонов. - Режим доступа: http://www.elitarium.ru/-

2007/03/23/socialnye_statusy_i_socialnye_roli.html.

10. Рогов Е. И. Учитель как объект психологического исследования: пособ. для шк. психологов по работе с учителем и пед. кол. / Е. И. Рогов. - М.: Гуманит. изд. центр ВЛАДОС, 1998. - 496 с.

11. Савченко О.Я. Якість початкової освіти: сутність і чинники впливу / О.Я. Савченко // Науковий вісник МДУ імені В.О. Сухомлинського. - Вип. 1 (33) «Педагогічні науки». - C.9-15 [Електронний ресурс]. - Режим доступу: http://m\#du.edu.ua/spaw2/uploads/files/4_8.pdf

12. Стань тренером для всех и во всем / Дж. Порше, Дж. Нидерер. - Ростов н/Д: Феникс, 2005. $-96 \mathrm{c}$.

13. Сухомлинский В. А. Избранные произведения : в 5 т. / В. А. Сухомлинский. - Київ : Рад. школа, 1979. - Т. 1. $-686 \mathrm{c}$

14. Хобзей П. Якість освіти у школі залежить від учителя, змісту та навчального середовища / П. Хобзей // [Електронний ресурс]. - Режим доступу: http://mon.gov.ua/usi-novivni/novini/2015/11/10/pavloxobzej-yakist-osviti-v-shkoli-zalezhi/

15. Frager R., Fadiman J. Glossary of «personality \& personal growth» [Електронний pecypc] / R. Frager, J. Fadiman. - Режим доступу : http:// vocabulary.ru/dictionary/36.

16. Kolb D. A. Experiential learning: Experience as the source of learning and development. Englewood Cliffs / D. A. Kolb. - N.J. : PrenticeHall, Inc., 1984.

17. Linton R. The study of a man : An Introduction. Paperback / R. Linton // Prentice Hall. -1936. - Jan 1.

18. Super D. E. et al. Vocational Development: A Framework of Research. - N.Y., 1957. - 391 p.

Олена Володимирівна Варецька, доктор педагогічних наук, доцент, професор кафедри початкової освіти, Комунальний заклад «Запорізький обласний інститут післядипломної педагогічної освіти», Запорізької обласної ради, в. Незалежної України, 57-А, м. Запоріжжя, Украӥна

\section{ОСОБИСТІСНО-ПРОФЕСІЙНИЙ КОМПОНЕНТ СОЦАЛЬНОӤ КОМПЕТЕНТНОСТІ} ВЧИТЕЛІЯ ПОЧАТКОВОЇ ШКОЛИ: РЕЗУЛЬТАТИ РОЗВИТКУ У ПІСЛЯДИПЛОМНІЙ ОСВІТІ

Актуальність проблеми зумовлена соціально-економічними викликами, євроінтеграційними змінами, зростанням ролі особистості в суспільних процесах, їі соціально-професійних якостей і здібностей на тлі перманентних реформувань освіти, зокрема й початкової, недостатньої орієнтованості програм підготовки майбутніх вчителів початкової школи у вищих навчальних закладах на формування соціальної компетентності, суттєвого переважання кількості працюючих учителів, які увійшли у стадію професійного розвитку «збереження» і «зниження», й відповідно, необхідністю постійної перепідготовки й підвищення їхньої кваліфікації. Метою статті є висвітлення результатів розвитку одного із шести компонентів соціальної компетентності вчителя початкової школи - особистісно-професійного у післядипломному освітньому процесі, доведенні широких можливостей цієї системи щодо створення відповідних сприятливих умов. Для досягнення поставленої мети використано такі методи: педагогічне спостереження, педагогічний експеримент для визначення вихідного та кінцевого рівнів розвитку соціальної компетентності учителів початкової школи з метою вирішення проблеми, зняття суперечностей; анкетування щодо предмету дослідження й одержання інформації про фактичний стан справ; тестування - для з'ясування рівня соціально-психологічних і соціально-педагогічних знань учителя, а також їхньої відповідності певним нормам шляхом 
аналізу способів виконання низки спеціальних стандартизованих завдань; самоаналіз та самооцінка учителем власних соціально-професійних здібностей, соціально-педагогічної та соціально-технологічної готовності до підвищення рівня соціальної компетентності в післядипломному процесі; експертна оцінка для об'єктивного оцінювання й характеристики явища, яке вивчається; метод моделювання - для розроблення структурно-функціональної моделі, за допомогою якої уточнювали сутність і характеристики досліджуваного процесу; математичні й статистичні методи для опрацювання фактичного матеріалу дослідження й оцінювання його результатів, доповнення якісних результатів науково-дослідної роботи кількісними. Описано деякі із заходів щодо підвищення ефективності розвитку соціальної компетентності у комплексному пролонгованому процесі упродовж п'яти років у формальній, неформальні та інформальній освіті. Виявлено нерівномірність розвитку різних компонентів, позитивну динаміку вихідних і кінцевих результатів за рівнями розвиненості особистісно-професійного компонента соціальної компетентності в учасників експериментальної групи у порівнянні з контрольною. Зіставлення середньоарифметичних величин узагальнених результатів цих груп засвідчує про їх суттєві відмінності і вказує на істотні зрушення, які відбулися за час проведення формувального етапу педагогічного експерименту, доводить можливості післядипломної освіти щодо створення відповідних умов для такого розвитку.

Ключові слова: соціальна компетентність, учитель початкової школи, післядипломна педагогічна освіта, особистісно-професійний компонент, результати розвитку.

Submitted on June, 20, 2017

UDC: $378.22: 373.61(043.3)$

\author{
Nataliia Chernenko, \\ Doctor of Pedagogy, associate professor, acting professor at the \\ Department of Educational Institutions Management and Civil Service, \\ South Ukrainian National Pedagogical University named after K. D. Ushynsky, \\ 26, Staroportofrankivska Str., Odessa, Ukraine
}

\title{
COGNITIVE COMPONENT MATURITY OF DIRECTORS' RISK MANAGEMENT SKILLS
}

The paper aims to present the results of the experiment focused at examining the cognitive component maturity of directors' risk management skills. In order to assess directors cognitive risk management skills according to "knowledge awareness/non-awareness" a testing form "Core of Risk Management at Educational Institutions", a minicase "Risk Management Procedure and Tools" were applied. The cognitive component of risk management skills provides the system of knowledge which should be mastered by directors and should act like a base for the formation of necessary skills for risk management at educational institutions. It can be determined by the following indices: knowledge of conceptual regulations of risk management at educational institutions, processes of management of risks at educational institutions, mastering methods of risks processing, ways of preventing and overcoming risks at educational institutions, logical and adapting thinking skills. The results of qualitative and quantitative indices of the assessment of performed testing tasks show insufficient knowledge of directors of theory and methods of risk management at educational institutions, which conditions the need for paying special attention to this fact as it is knowledge which is the core of directors' risk management skills in terms of educational institutions.

Keywords: knowledge, cognitive component, director, risk, risk management.

\section{Introduction}

The studying of any science should be based on the groundwork, initial observations and statements, investigating those fact which are the foundation of its pyramid structure. One cannot build a pyramid starting from the top, the construction is possible just from its foundation. That is why the maturity of cognitive component of directors' risks management skills is the basis of professional activities in this field.

The analysis of scientific both domestic and foreign literature shows the necessity of implementing the issues covering the formation of future experts' methodological, system knowledge in the educational process (according to [1], [2], [3], [4], [6], [8], [9]).

Cognitive component involves a system of knowledge that should be mastered by future directors and act like a basis of the formation of necessary skills for risk management. Cognition is a key concept in this phenomenon which means a set of mental processes - perception, categorization, thinking, speaking, etc., which help to process information.

The foundations of cognitions and their development was examined in the works of L. Vygotsky, who dealt with not only the development of human intelligence and 